\title{
DAMPAK PERKAWINAN CAMPUR ETNIK BATAK - SUNDA TERHADAP INTEGRASI SOSIAL
}

\author{
Endah Ratna Sonya \\ Universitas Islam Negeri Sunan Gunung Djati Bandung \\ endahratna.sonya@uinsgd.ac.id
}

\begin{abstract}
The married family of Batak-Sunda ethnic group in Cijerah Village with different ethnic and cultural unity in one family through marriage, become husband and wife in the beginning there is symptom of not harmonious, but because of the bond of love and affection both ethnic and cultural differences finally become problem in their home life. Important factors in instilling adaptation of parents of married Batak-Sunda married families to their children, various forms of application include balance of attention, family unity, the application of rewards, punishment and external factors. It also has a great influence on adaptation of children.
\end{abstract}

Keywords: Social Integration, Mixed Marriage, Batak. Ethnic, Sundanese Ethnicity

\begin{abstract}
Abstrak
Keluarga kawin campur etnik Batak-Sunda di Kelurahan Cijerah yang berbeda etnik dan kebudayaan menyatu dalam satu keluarga melalui perkawinan, menjadi suami-isteri pada awalnya ada gejala tidak harmonis, namun karena ikatan rasa cinta dan kasih sayang keduanya akhirnya perbedaan etnik dan budaya tidak menjadi masalah dalam kehidupan rumah tangga mereka. Faktor-faktor yang penting dalam menanamkan adaptasi orang tua keluarga kawin campur Batak-Sunda kepada anaknya, bermacam-macam bentuk penerapan di antaranya perimbangan perhatian, keutuhan keluarga, penerapan ganjaran, hukuman dan faktor eksternal. Hal itupun mempunyai pengaruh besar terhadap adaptasi anak.
\end{abstract}

Kata Kunci: Integrasi Sosial, Perkawinan Campur, Etnik Batak, Etnik Sunda

\section{A. Pendahuluan}

Kota Bandung -seperti kota-kota lainnya- merupakan tempat bagi berbagai etnik yang berbeda, bertemu dan saling berinteraksi untuk bekerjasama, berteman dan berkeluarga (melakukan perkawinan campur dengan etnik Sunda). Interaksi yang dilakukan oleh masyarakat pendatang dari luar etnik Sunda biasanya akan lebih sulit dan bersifat lebih kompleks, karena mereka harus dapat menyesuaikan diri dengan lingkungan dan kebudayaan yang sama sekali berbeda dengan daerah asalnya, sehingga pada akhirnya, melalui proses adaptasi tersebut, akan terjadi perubahan 
prilaku yang menyangkut aktivitas keseharian, seperti gaya berbicara, bersikap, cara makan, cara menyapa, bahkan perubahan dalam hal penggunaan bahasa.

Kualitas keberhasilan beradaptasi serta tingkat perubahan yang terjadi ditentukan pula oleh faktor-faktor internal. Faktor internal dalam diri seseorang antara lain kepribadian, pandangan hidup, prinsip-prinsip perorangan, juga bisa bersumber dari nilai-nilai dan norma-norma kebudayaan dari internalisasinya. Di antara faktor-faktor internal adalah pengaruh sistem kekerabatan terhadap proses adaptasi sosial dalam perkawinan campur antara pendatang etnik Batak dengan orang Sunda di Kelurahan Cijerah Kota Bandung. Faktor eksternal yang berupa perbedaan bahasa, tingkah-laku dan cara hidup atau kebiasaan-kebiasaan lainnya akan lebih mempengaruhi pada saat para perantau tersebut memulai interaksinya dengan orangorang dari etnik yang berbeda. Di kota, kepribadian etnik seperti etnik Batak dan Sunda sudah sulit untuk digeneralisasikan. Hal ini mungkin masih tersisa sebagai suatu stereotip saja. Adanya perkawinan campur antar etnik yang ada pada masyarakat Indonesia seperti perkawinan campur antara orang Batak dengan orang Sunda telah terjadi sejak lama, misalnya di Kelurahan Cijerah Kota Bandung yang sudah melembaga menjadi keluarga atau rumah tangga. Apa yang dimaksud dengan masyarakat Batak di sini adalah masyarakat Batak di Indonesia khususnya di Kota Bandung, yaitu yang lahir dan cukup lama / baru tinggal di Kelurahan Cijerah Kota Bandung.

Biasanya dalam proses adaptasinya, masyarakat pendatang akan mengalami hambatan atau benturan karena perbedaan latar belakang sosial-budaya yang mereka miliki dengan lingkungan dan budaya lokal, yaitu masyarakat dengan budaya Sundanya. Perbedaan bahasa, tingkah-laku dan cara hidup atau kebiasaan lainnya akan memerlukan suatu strategi penyesuian diri yang tinggi. Perbedaan akan mempengaruhi hubungan-hubungan antar personal dalam perkawinan campur etnik Batak - Sunda di Kelurahan Cijerah Kota Bandung.

\section{B. Tinjauan Pustaka}

Prinsip keturunan penting diketahui jenisnya dalam pengaturannya untuk mengetahui garis keturunan kelompok kerabat mana yang diikuti seorang anak yang dilahirkan oleh setiap keluarga. Jenis prinsip keturunan yang berlaku secara umum dalam kehidupan masyarakat Indonesia terdiri dari prinsip keturunan patrilineal, 
matrilineal, bilineal dan bilateral (Murdock, 1949: 15). Perkawinan secara eksogami menuntut agar seseorang memilih jodoh dari luar kelompoknya sendiri. Banyak masyarakat memperluas lingkaran dengan perkawinan antar klas, antar kampung, bahkan kadang-kadang antar suku dan agama. Perkawinan campur menurut Cohen 1979 (Hariyono, 1993; Kartikasari, 2017) berlangsung antara individu dari kelompok etnik yang berbeda, lazimnya disebut amalgamasi.

Dalam kehidupannya sebagai makhluk sosial, manusia selalu berinteraksi dengan sesamanya dan bahkan berupaya untuk saling melakukan adaptasi dirinya dengan sesama manusia. Adaptasi terjadi sepanjang hidup manusia, karena merupakan proses kognitif (proses pemikiran) yang timbul, diterapkan dalam kehidupan manusia. Sedangkan, dalam kaitannya dengan ciri etnik berfungsi sebagai kategori untuk menentukan pengelompokan dan untuk beradaptasi, dan agar perilakunya dihargai, seseorang harus menyesuaikan diri atau beradaptasi dengan kategori ini. Budaya juga menyediakan sejumlah peralatan analisis untuk mempelajari prilaku adaptasi. Penggunaan konsep adaptasi yang paling bias adalah dengan menghubungkan pasangan nilai, keteladanan, model atau gaya yang dapat dipilih oleh semua orang agar dapat mengendalikan keputusan dan kegiatannya, yang berdasarkan pilihan secara sadar ataupun tidak sadar sebagai hasil penyelarasan yang diterima dalam proses sosialisasi (Hughes, 2008). Mengkaji proses adaptasi sangat erat kaitannya dengan menganalisis kebudayaan itu sendiri. Kebudayaan pada dasarnya memiliki eksistensi dalam ruang dan waktu, yaitu: (1) di dalam organisme manusia; (2) di dalam proses interaksi sosial; dan (3) di dalam benda-benda yang bersifat materil (Leslie dalam Bennet, 1976: 235). Dari eksistensi tersebut, maka kebudayaan mempunyai wujud baik dalam bentuk ide, proses sosial maupun hasil dari proses sosial dalam wujud karya manusia. Keterkaitan antara kebudayaan dengan sistem adaptasi, Keesing (dalam Bennet, 1976: 74-76) menjelaskan sebagai berikut:

1. Kebudayaan merupakan sistem dari pola perilaku yang disalurkan secara sosial.

2. Kebudayaan sebagai sistem adaptif, merupakan mekanisme umpan balik pada sistem budaya, yaitu terjadinya perubahan kebudayaan ke arah keseimbangan (equilibrium) di dalam suatu ekosistem.

3. Sentral bidang kebudayaan yang paling adaptif adlah teknologi, ekonomi, mencari nafkah dan unsur-unsur organisasi sosial yang terikat dengan produksi. 
4. Komponen-komponen ideasional dari sistem kultur mempunyai akibat adaptif di dalam mengawasi atau mengontrol populasi, membantu mencari nafkah, memelihara ekosistem dan sejenisnya.

Terdapat kecenderungan perbedaan dalam melakukan adaptasi, maka Bennet (1976; 2017) menyarankan agar dalam mempelajari adaptasi harus dilihat dari tiga kunci persoalan, yaitu; perilaku adaptasi, tindakan adaptasi, dan srategi adaptasi.

Perilaku adaptasi merupakan perwujudan perilaku yang harus disesuaikan dengan tujuan yang hendak dicapai. Bentuk-bentuk perilaku ini dipilih dan disesuaikan dengan tujuan, sehingga penolakan atau keterlibatan adalah sebagai pilihan perilaku yang semata-mata bermaksud untuk beradaptasi. Perilaku adaptasi dapat dilakukan dalam kaitan dengan tujuan yang hendak dicapai. Apabila tujuan tersebut menguntungkan maka perilaku adaptasi diupayakan dan disesuaikan dengan sebaik-baiknya dengan tujuan yang telah ditetapkan.

Tindakan adaptasi bermakna suatu tindakan yang secara khusus direncankan dan dilakukan sekuat tenaga (maksimal) dan diarhkan untuk kemajuan-kemajuan di masa depan. Perancangan dan perwujudan tindakan dilakukan secara logis melalui pikiran yang rasional. Untuk itu tindakan adaptif lebih bersifat tindakan penyelesaian, bilamana terdapat kekurangberesan dalam perilaku adaptif. Tindakan adaptif cenderung bersifat menerima.

Strategi adaptif mengacu pada tindakan-tindakan yang telah dipilih secara sistematis dalam bentuk pengambilan keputusan. Upaya untuk membuat keputusan itu menurut Bennet, dilakukan karena individu atau kelompok yang bersangkutan telah memprediksi bahwa dengan memanfaatkan sumber dayanya, mereka akan berhasil dalam mencapai tujuan. Pada strategi adaptif ini, menurut Bennet sudah terkandung langkah-langkah yang akan ditempuh dan memperhitungkan masalahmasalah yang akan dihadapi.

\section{Metode Penelitian}

Penelitian ini mengambil pendekatan kualitatif dan dijelaskan secara deskriptif. Pengambilan data dilakukan dengan cara observasi dan wawancara terhadap lima keluarga yang melakukan perkawinan campur di Kelurahan Cijerah, Kota Bandung pada tahun 2017. Analisis dilakukan dengan model interaktif ala Miles 
dan Huberman (1994), yaitu dengan cara reduksi data, penyajian data, dan penarikan kesimpulan atau verifikasi.

\section{Proses Adaptasi Sosial}

\section{Adaptasi di Keluarga Batih}

Hubungan berdasarkan sistem kekerabatan atau adat istiadat ini telah diadaptasikan kepada anak-anak sejak dia mulai mengenal lingkungannya yang paling dekat, yaitu tokoh-tokoh yang paling dekat dalam kehidupan terutama ibu, bapak dan saudara-saudaranya. Orang lain di luar dirinya secara evolusionistis diperkenalkan sesuai dengan sistem kekerabatan Bapak yaitu Batak Toba/Batak Mandailing (daliban na tolu) atau sistem kekerabatan Sunda. Bersamaan dengan perkenalan orang-orang lain itu, diperkenalkan kepadanya marga dan nilai yang terkandung didalam pengertian marga lengkap dengan kode etik dalihan na tolu, bagi keluarga perkawinan campur dengan Bapak Batak Toba/Batak Mandailing. Pada keluarga perkawinan campur dengan Bapak Sunda anak-anak diperkenalkan kepada silsilah keluarga inti dan keluarga luas umumnya. Termasuk dalam proses adaptasi awal ialah perkenalan tutur atau panggilan kekerabatan lengkap dengan kata-kata kunci yang terdapat dalam perbendaharaan hubungan kekerabatan berdasarkan sistem kekerabatan Bapak yaitu Batak Toba/Batak Mandailing (daliban na tolu) atau sistem kekerabatan Sunda.

Keluarga adalah unit sosial pertama yang menjadi wadah adapatasi nilai-nilai budaya kepada anak-anak yang dilahirkan dalam kelurga tersebut. Anak-anak pertamakali berinteraksi dengan orang-orang lain di lingkungan sosialnya juga di mulai dalam lingkungan keluarga batih. Anak-anak belajar mengenal peranan dan kedudukan sosial juga dan lingkungan anggota keluarga. Singkatnya, apa yang diketahui oleh anak-anak berkenaan dengan kehidupan sosialnya akan dia peroleh dari lingkungan anggota keluarga. Dengan demikian, kelurga juga merupakan unit sosial pertama yang berfungsi untuk mendidik anak-anak.

Keluarga batih, pada hakekatnya dapat dibagi dalam tiga kategori, yakni,

1. Melihat keluarga batih sebagai arena adaptasi. Dalam keluarga itu peranan orang tua adalah mengajarkan dan mewariskan nilai-nilai sosial dari masyarakatnya kepada anak-anak mereka, dan langsung maupun tak langsung orang tua merupakan agen bagi mempertahankan keteraturan sosial dari masyarakat itu yang 
telah ada. Dengan melihat keluarga merupakan penghubung antara masyarakat dan individu.

2. Melihat keluarga batih sebagai suatu arena interaksi dari status-status dan perananperanan yang berbeda. Dan bagaimana status dan peranan yang berbeda itu sebenarnya merupakan suatu perwujudan konflik. Dengan demikian pada hakekatnya konflik antar peranan dan status dalam keluarga itu menjaga keberlangsungan struktur keluarga batih.

3. Melihat keluarga batih sebagai suatu hubungan komunikasi antar anggota keluarganya. Hubungan komunikasi itu dilihat sebagai suatu bentuk interaksi simbolik yang masing-masing dapat mencerminkan status dan peranannya dalam keluarga itu. Dengan demikian mempelajari keluarga merupakan unit analisa yang sebenarnya ingin menggambarkan keadaan masyarakatnya. Dengan melihat keluarga sebagai suatu arena interaksi simbolik berarti keluarga merupakan cermin dari masyarakatnya.

Kebiasaan-kebiasaan orang tua secara langsung maupun tak langsung memberi pengaruh terhadap anak-anaknya. Mulai kecil sampai dewasa, anak berkumpul bersama orang tuanya dalam satu wadah yang disebut dengan keluarga. Mereka, si anak, memperoleh sejumlah norma yang nantinya digunakan sebagai pedoman bagi pergaulannya di lingkungan yang lebih luas.

\section{Adaptasi di Keluarga Luas}

Dalam tradisi masyarakat Batak Toba, Batak Mandailing dan Sunda masa lalu proses adaptasi dan sosialisasi tidak hanya menjadi urusan keluarga inti. Sejak seorang anak lahir, dia secara terus-menerus bergaul dengan orang tua dan saudarasaudaranya yang lain. Tapi selain itu dia juga secara terus-menerus pula mendapat perhatian dari anggota kerabat lain dari lingkungan keluarga luasnya, misalnya dari kakek, paman, bibi, saudara sepupunya, dan sebagainya. Keterlibatan para kerabat dari keluarga luas dalam proses adaptasi dan sosialisai anak tersebut menjadikan anak secara dini mengenal dengan baik orang-orang yang sekerabat dengannya, mengetahui kedudukan dan peranan sosial yang dimainkan oleh setiap orang dalam pergaulan sehari-hari, dan juga mengetahui posisi dan peranan yang harus dimainkan ketika berhubungan dengan orang-ornag tersebut. 
Interaksi sosial yang cukup intensif dengan anggota kerabat dari keluarga luas tersebut secara dini telah membentuk rasa kebersamaan pada diri anak, sehingga sejak kecil dia telah mengetahui pentingnya menjalin hubungan yang baik dengan para kerabat. Rasa kebersamaan itu pada masa yang lalu diperkuat oleh tradisi makan bersama dari piring yang sama yang menjadi kebiasaan etnik Batak Toba, Batak Mandailing dan Sunda. Karena kebiasaan tersebut maka mereka yang bersaudara semakin erat hubungan persaudaraannya. Begitulah anak-anak diadaptasikan dan disosialisasikan dengan nilai-nilai kebersaaman sejak masih kecil sehingga dimasa dewasa mereka akan muncul sikap yang penuh peduli pada sesama manusia, terutama kepada semua kerabat.

Kuatnya rasa kebersamaan dikalangan anggota keluarga yang berkerabat dalam lingkup keluarga luas menyebabkan setiap orang merasa bertanggung jawab untuk ikut mendidik anggota kerabtnya yang lain ke jalan yang benar dalam kaitan ini, ada yang membuat tafsiran bahwa nilai budaya Batak Toba, Batak Mandailing dan Sunda yang mendorong mereka untuk memiliki anak sebanyak-banyaknya itu pada hakekatnya adalah nilai yang mendorong agar seseorang menaruh tanggungjawab kepada anak-anak dan saudara-saudaranya yang lain yakni mereka yang termasuk bukan anak kandungnya sendiri. Artinya, seseorang atau sebuah kelurga harus menyikapi bahwa anak-anak lain yang dimiliki oleh saudara-saudaranya juga merupakan anaknya juga, sehingga dia harus menaruh perhatian pula terhadap proses adaptasi dan sosialisasi pada keluarga Batak Toba, Batak Mandailing dan Sunda masa lalu sangat kuat mengutamakan rasa kebersamaan dan tanggungjawab terhadap sesama kerabat.

Satu hal yang mendasari sikap demikian adalah nilai kebersamaan yang sangat penting dalam kehidupan sebuah keluarga. Dalam tradisi Batak Toba, Batak Mandailing dan Sunda dikatakan bahwa orang yang memiliki harta berlimpah belum bisa mendapatkan predikat terhormat dan dimuliakan apabila mereka hanya mementingkan dirinya sendiri. Nilai kebersamaan antara lain dapat dicirikan oleh adanya sifat kearifan dan kebijaksanaan, memiliki kharisma dan wibawa, berakhlak mulia, sehingga dengan itu dia dihormati atau menjadi orang yang terpandang di lingkungan sosialnya. Sifat-sifat tersebut terutama ditujukan kepada orang-orang yang ada di lingkungan sosialnya yang terdekat, yaitu para kerabatnya. Dalam ungkapan tradisional disebut bahwa kalu ingin memiliki nilai kebersamaan maka harus rukun 
bersaudara. Inti dari nilai kebersamaan itu adalah adnya rasa kasih sayang kepada sesama, terlebih-lebih kepada sesama saudara (kerabat).

Sebagai sebuah wadah adaptasi dan sosialisasi, maka keluarga sebagai inti sosial terkecil pada masyarakat Batak Toba, Batak Mandailing dan Sunda berfungsi sebagai wadah untuk mengajarkan nilai-nilai budaya, mengajarkan kepada anak-anak mereka yang dianggap baik dan berharga dalam hidup ini. Di dalam keluarga itu diajarkan pula secara lisan maupun melalui contoh berupa tindakan nyata bagaimana semua hal-hal yang paling berharga dalam hidup itu harus diperjuangkan untuk bisa dicapai.

Para informan yang diwawancarai di Kelurahan Cijerah mengungkapkan peranan keluarga dalam fungsi adaptasi dan sosialisasi ini telah banyak mengalami perubahan dibandingkan dengan keadaan yang lazim berlaku di masa lalu. Jika pada masa lalu keluarga yang bertanggungjawab atas proses adaptasi dan sosialisasi itu bukan hanya anggota keluarga inti, akan tetapi juga mereka yang termasuk anggota keluarga luasnya, maka pada masa sekarang peranan itu lebih dominan berada di pundak anggota-anggota keluarga inti saja.

Kehidupan di lingkungan yang baru atau daerah baru dengan orang-orang yang berasal dari daerah yang berbeda-beda, oleh informan disebutkan sebagai salah satu alasan yang menyebabkan peranan keluarga luas dalam proses adaptasi dan sosialisasi ini menjadi berkurang. Selain itu, pergaulan hidup di alam modern ini dengan segala macam sumber informasi yang dengan mudah diakses oleh setiap orang mengakibatkan terjadinya erosi terhadap nilai-nilai kebersamaan yang diajarkan oleh tradisi lama. Para informan menyebutkan hubungan-hubungan kekerabatan yang masih mengikat satu orang dengan orang lain atau satu keluarga dengan keluarga lain dalam konteks sebuah keluarga luas tidak dengan sendirinya lagi mendorong para anggota untuk merasa ikut bertanggungjawab atau penerus nilai-nilai dan proses adaptasi orang lain di luar kerabat intinya. Sebagai contoh, seorang yang berstatus paman terhadap seorang remaja anak dari saudaranya tidak lagi hirau dan ikut mengingatkan apabila remaja tersebut melakukan suatu tindakan yang kurang baik. Dari pihak anak-anak juga telah timbul sikap kurang menghormati anggota kerabat jauhnya, sehingga mereka tidak merasa terikat terhadap aturan yang diterapkan oleh kerabat jauh tersebut. 
Namun demikian, dalam tatanan hubungan sosial, pengakuan terhadap pentingnya anggota kerabat dari keluarga luas masih tetap dipelihara. Hal itu terlihat dari kehadiran anggota kerabat dalam setiap upacara adat (misalnya upacara perkawinan dan kematian) yang dilangsungkan di lingkungan desa. Dengan demikian, yang mulai berubah adalah peranan dan tanggungjawab kerabat dalam ikut serta membina adaptasi anggota kerabat lainnya di lingkungan keluarga luas.

Keterikatan dengan sistem kekerabatan asal setelah menikah pada isri Batak dan istri Sunda berbeda. Pada istri Batak apabila menikah dengan suami Sunda maka putuslah keterikatan dengan sistem kekerabatan asal, sehingga tidak diwajibkan lagi untuk ikut serta dalam kegiatan-kegiatan adat yang diadakan oleh keluarga besarnya. Sedangkan pada istri Sunda apabila menikah dengan suami Batak maka masih terikat dengan sistem kekerabatan asal, karena masyarakat Sunda mengenal sistem kekerabatan yang disebut sa-bondoroyot. Sehingga istri Sunda masih tetap akan diakui oleh sistem kekerabatan asalnya.

\section{Pembauran dengan Penduduk Setempat}

Pada bagian ini akan dipaparkan tentang nilai-nilai atau prinsip-prinsip budaya yang dipegang oleh sebagain besar masyarakat Sunda pada umumnya, dan suku Batak Toba/Batak Mandailing pada khususnya. Prinsip-prinsip budaya, seperti rasa hormat, kesopanan, kerukunan, dan rasa malu, telah mengakar dan diwariskan secara turun-temurun dalam masyarakat Sunda. Bagian ini akan memberikan suatu pemahaman mengenai kemungkinan terbentuknya bangunan identitas yang baru pada Batak Toba/Batak Mandailing pendatang, yang hanya dimungkinkan oleh adanya pengaruh lingkungan kultural Sunda yang dominan terhadapnya.

Berdasarkan data-data yang diperoleh, terdapat beberapa data yang mengindikasikan terbentuknya identitas etnik baru dikalangan Batak Toba / Batak Mandailing pendatang yang tinggal di lingkungan Sunda. Identitas etnik itu berupa perubahan-perubahan prilaku yang mengacu pada perubahan-perubahan pandangan, pemahaman, dan pemaknaan dalam melihat perbandingan dirinya yang menyandang etnik tertentu dengan masyarakat etnik sunda yang melingkupinya. Di mana identitas etnik yang baru itu berbeda dari identitas etnik yang mereka tentukan secara sadar, yang masih terkait dan terikat dengan daerah asal mereka. Selain itu, identitas etnik itu 
juga tidak terlihat indikasi kehadirannya ketika ia belum bersentuhan dengan budaya sunda. Namun, identitas itu muncul pada saat ia kembali ke kampung halamannya.

Bahasa menjadi alat yang efektif dan sangat membantu dalam proses adaptasi tersebut. Hal ini dikarenakan para informan mengalami kesulitan berkomunikasi dengan masyarakat yang secara mayoritas beretnik Sunda. Karenanya, hambatan dalam berkomunikasi itu cenderung menjadi pemicu Batak Toba/Batak Mandailing pendatang untuk belajar memahami dan menguasai bahasa Sunda. Proses belajar tersebut pada kebanyakan Batak Toba/Batak Mandailing pendatang tersebut, menjadi awal dari usaha mereka untuk beradaptasi dengan budaya setempat. Karena itulah maka bahasa menjadi pembuka bagi terciptanya interaksi yang lebih sejalan antara etnik Batak Toba/Batak Mandailing dengan etnik Sunda yang merupakan penduduk asli di Kelurahan Cijerah.

Strategi adaptasi pendatang etnik Batak yang beragama Kristen maupun Islam dengan etnik Sunda yang merupakan penduduk asli di Kelurahan Cijerah tidak jauh berbeda, karena strategi adaptasi sosial yang dijalankan tidak berdasarkan perbedaan agama tetapi merupakan strategi adaptasi terhadap kebudayaan yang berbeda dengan tetap menghormati tradisi dan adat istiadat etnik lain dalam konteks hubungan antar etnik yang harmonis.

\section{E. Kesimpulan}

Beberapa kesimpulan yang dapat diambil dari hasil penelitian sistem kekerabatan dan proses adaptasi sosial dalam perkawinan campur etnik Batak-Sunda di Kelurahan Cijerah adalah:

1. Faktor-faktor yang penting dalam menanamkan adaptasi orang tua keluarga kawin campur Batak-Sunda kepada anaknya, bermacam-macam bentuk penerapan diantaranya perimbangan perhatian, keutuhan keluarga, penerapan ganjaran, hukuman dan faktor eksternal. Hal itupun mempunyai pengaruh besar terhadap adaptasi anak.

2. Hubungan kekerabatan diantara orang-orang Batak Toba / Mandailing itu sangat kuat dan mempunyai fungsi dan arti yang penting dalam kehidupan mereka. Orang batak Toba / Mandailing tidak terintegrasi secara penuh dengan masyarakat kota dan tidak berasimilasi secara penuh dengan budaya kota. 
3. Keterikatan dengan sistem kekerabatan asal setelah menikah antara istri Batak dan istri Sunda berbeda. Pada istri Batak apabila menikah dengan suami Sunda, maka tidak terikat lagi dengan sistem kekerabatan asal. Sedangkan pada istri Sunda apabila menikah dengan suami Batak, maka masih akan terikat dengan sistem kekerabatan asal, karena pada etnik Sunda mengenal sistem kekerabatan yang disebut sa-bondoroyot.

\section{Daftar Pustaka}

Allan, A. Graham. 1979. Sociology of Friendship and Kinship. London: George Allen \& Unwin Ltd.

Bennet, J. W. 1976. Anticipation, Adaptation, and Concept of Culture al in Anthropology. Science.

Bennett, J.W., 2017. The ecological transition: cultural anthropology and buman adaptation. Routledge.

Budhisantoso, S. 1988. Sistem Kekerabatan dan Pola Pewarisan. Jakarta: PT Pusaka Grafika Kita.

Cohen, Bruce J. 1979. Introduction to Sociology. New York: Mc. Graw Hill Book Company.

Ekadjati, Edi S. 1995. Kebudayaan Sunda (Suatu Pendekatan Sejarab). Jakarta. Pustaka Jaya.

Fox, Robin. 1966. Kinship and Marriage. Kingston: a Pelican Original.

Garna, Judistira K. 1995. Sistem Budaya Indonesia. Bandung: Program Pascasarjana Universitas Padjadjaran.

Hariyono, P. 1993. Kultur Cina dan Jawa Pemahaman Menuju Asimilasi Kultural. Jakarta: Pustaka Sinar Harapan.

Hughes, D., Rivas, D., Foust, M., Hagelskamp, C., Gersick, S. and Way, N., 2008. How to catch a moonbeam: A mixed-methods approach to understanding ethnic socialization processes in ethnically diverse families. Handbook of race, racism, and the developing child, pp.226-277.

Kartikasari, R.G. and Haryanti, Y., 2017. Communication Pattern Of Mixed Marriage (A Qualitative Study on the Mixed Marriage Parents Educating Their Children) (Doctoral dissertation, Universitas Muhammadiyah Surakarta).

Keesing, Roger M. 1992. Antropologi Budaya: Suatu Perspektif Kontemporer. Jilid I. (Alih bahasa: Samuel Gunawan). Jakarta: Erlangga.

Koentjaraningrat. 1997 [1971]. Manusia dan Kebudayaan di Indonesia. Jakarta: Djambatan.

Martodirdjo, Haryo S. 1991. Orang Tugutil di Halmahera Struktur dan Dinamika Sosial Masyarakat Pengbuni Hutan. Bandung: Disertasi Program Pascasarjana UNPAD.

Martodirdjo, Haryo S. 2005. Studi Hubungan Antar Etnik. Bandung: Pascasarjana UNPAD.

Miles, M.B., Huberman, A.M., Huberman, M.A. and Huberman, M., 1994. Qualitative data analysis: An expanded sourcebook. sage.

Murdock, George Peter. 1965. Social Structure. New York: The Free-Press. 
Siahaan, N. 1964. Sedjarah Kebudajaan Batak. Suatu Studi Tentang Suku Batak. Medan: C.V. Napitupulu \& Sons.

Suparlan, Parsudi. 1989. Sistem Kekerabatan, Keluarga, dan Peranan Pria Dalam Keturunan. Karangan Berita Antropologi Th. XIII No. 46 April- Juni. 